\title{
Intangible Cultural Heritage as Tourism Resource of Serbia
}

\author{
Branko Krasojevic $^{1, *}$, Biljana Djordjević ${ }^{2}$ \\ "Consultant in Tourism" Agency, Serbia \\ ${ }^{2}$ National Museum in Belgrade, Serbia
}

Copyright $\mathrm{O} 2017$ by authors, all rights reserved. Authors agree that this article remains permanently open access under the terms of the Creative Commons Attribution License 4.0 International License

\begin{abstract}
Intangible cultural heritage, as a factor of promoting and developing cultural and national identity, is the focus of attention of the UNESCO, UNWTO and other international organizations specializing in the protection and promotion of culture and tourism, thereby generating tourism demand. The tourist offer of Serbia includes intangible cultural heritage which is modestly and inadequately presented and interpreted. This project is the result of research for the development of national strategies in tourism and the investigations of the intangible cultural heritage as a tourism potential. Its aim is to highlight the importance of intangible heritage as a factor involved in generating the critical mass of the contemporarily interpreted cultural tourism products which can significantly enhance the competitiveness of the tourist offer of Serbia.
\end{abstract}

Keywords Intangible Cultural Heritage, Cultural Tourism, Creative Tourism, Competitiveness, UNESCO, Serbia

\section{Introduction}

Intangible cultural heritage attained its full recognition after the UNESCO adopted the relevant Convention in 2003. ${ }^{1}$ This Convention defined it for the first time, and provided recommendations for the preservation, protection and revitalization of this specific category of cultural heritage. This means that the intangible cultural heritage is recognized in areas such as oral traditions, performing arts, customs and rituals, the knowledge and skills involved in old

1 The Convention about preservation of intangible cultural heritage was adopted in UNESCO on the $17^{\text {th }}$ of October, 2003.

http://www.unesco.org/culture/ich/index.php?lg=en\&pg=00006

(12.13.2014). Till May of 2014, The Convention was ratified, accepted or approved by 161 countries. crafts and handicrafts. ${ }^{2}$ Promotion of intangible cultural heritage under this Convention is implemented through three lists, which include the representative heritage of humanity, heritage in need of an urgent protection and examples of the good practice. ${ }^{3}$ The main objective of the Convention for the preservation of the Intangible Cultural Heritage is its protection and revitalization. In fact, the term revitalization does not mean the revival of extinct and forgotten traditions, knowledge and skills. However, it means encouragement to those who in spite of the negative impacts on globalization persist in cultivating their local traditions which identify them as a community or a group, and by the transfer to the younger generation endeavor to ensure continuity of the identity which defines them. Therefore, raising the awareness of local communities and groups that foster certain elements of intangible cultural heritage and their education is of crucial importance [1]. The best way to implement this strategy is to emphasize the importance of intangible cultural heritage to a wider local and global community through the concept of integrated care [2]. Cultural tourism as a branch of the economy with a prominent educational role can significantly contribute to the implementation of this strategy, as it allows local communities not only to recognize the importance of expanding their traditions, but also to make it sustainable, thus facilitate its preservation and transmission to the next generation. In this sense, current achievements in this field and potentials that are yet to be used were observed.

\section{Culture and Tourism}

Culture and Tourism have been increasingly more linked together. Interest in culture and cultural programs, including those on intangible cultural heritage, is constantly

\footnotetext{
2 http://www.unesco.org/culture/ich/index.php?lg=en\&pg=00024

(12.13.2014).

$3 \mathrm{http}: / /$ www.unesco.org/culture/ich/en/lists
} 
increasing. ${ }^{4}$ Cultural tourism has a long tradition and the definition of it was changing over times [3]. Now we could say that the modern cultural tourism is a very complex way of meeting the needs of individuals and groups that expect much more than just a tour of cultural and historical monuments or museums during their visit. Tourists are increasingly interested in different cultures, performing arts, crafts, rituals, gastronomy and interpretations of nature and the universe. Judging by the indicators of interest that tourists have shown in the recent years, it could be said that the time of cultural tourism, in this sense, is yet to come [4]. World Tourism Day in 2011 was celebrated around the world under the slogan "Tourism - linking cultures" 5 which indicates a growing awareness of the importance of cultural interaction that encourages dialogue, builds understanding and promotes tolerance. The growth of cultural tourism is also reflected in the financial performance. It is estimated that these tourists spend a third more than an average tourist [5], which ranks cultural tourism among top ten "hot" market segments [6], as the growing offer of cultural activities affects the increase of its competitiveness [7]. Such a growing trend of interest in cultural tourism provides an opportunity for cultural heritage as a resource for development to become sustainable, bringing benefits to the local and wider community with the prerequisite for its preservation. Increasingly popular concept of cultural tourism in recent years is creative tourism. It was founded only fifteen years ago, and its creators, Richard Greg and Crispin Raymond, defined creative tourism as: "Tourism which offers visitors the opportunity to develop their creative potential through active participation in courses and learning experiences which are characteristic of the holiday destination where they are undertaken "[8]. A good example of this concept with tourists and tourist services providers, be it the travel agencies or local communities, is the fact that it is formed by the International Creative Tourism Associates (CTA) "to advise cities, states, provinces and countries on the application of Creative Tourism as an effective economic and community development tool". ${ }^{6}$ For many years, it successfully operates Creative Tourism Network, whose slogan is intended for tourists " I am not a tourist. I am a creative tourist. Learn - Connect - Be Inspired".?

How does Serbia as a tourist destination fit into this trend?

The most developed countries of the world promote their cultural heritage for tourism purposes and have invested

4 The World Tourism Organization states that the number of tourists in cultural tourism increased from $37 \%$ in 1995 to $40 \%$ in 2004. Organization for Economic Co-operation and Development (OECD) in a report from 2009 , confirmed that cultural tourism in 2007, represents a motive for the nearly 360 million international tourist travels, which accounts for about $40 \%$ of the total world tourism. http://www.tram-research.com/atlas/APC $\%$ 20Paper\%20Greg\%20Richards.PDF

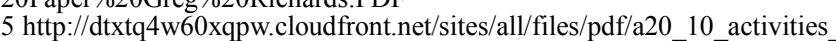
wcte election_members_new_wcte_part_i_en.pdf (20.12.2014.), Study on

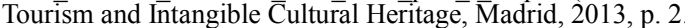

6International Creative Tourism Associates: http://www.creativetourism.or $\mathrm{g} /$.

7Creative Tourism Network:http://www.creativetourismnetwork.org/abou t/. great efforts to understand and promote it, while countries in transition (such as Serbia) are lagging behind even though they have great potential as the countries rich in cultural tourism [9]. Serbia has not yet approached this problem systematically. There is no strategy for the development of cultural tourism as a potential stressed in the Results of the project Support to the Implementation of the National Strategy of tourism development in Serbia 2010-2012. Linking culture and tourism, for now, is conducted sporadically, as a personal initiative of individual tourist workers and not as a system solution with a clear concept of development and financial goals. Research conducted in 2014, showed that out of 102 consulted travel agencies in the capital Belgrade, only 42 had offered Serbia as a destination, 17 offered cultural tourism and creative tourism programs are offered by only one agency [10]. Serbia could turn this weakness into an advantage, because great potential in under-exposed intangible cultural heritage could increase the competitiveness of its tourism offer by adding quality and volume, and thus contribute to raising the awareness about local communities and help preservation. The change requires appropriate presentation and interpretation of intangible cultural heritage $[11] .^{8}$

\section{From Cultural Resources to Cultural Tourism Products}

All tangible and intangible, natural and cultural heritage, as environmental factors, represent tourist resources and can be used for tourism purposes to produce an economic impact and contribute to the economic development of specific destinations. Cultural resources can become tourism resources only by planned creation, just like cultural products do after the process of presentation and interpretation. Cultural tourism and the economic value of the resource is estimated based on the degree of attractiveness, aesthetic impression, details, attractions, and benefits of geographical location, as well as by distance and traffic connections with the tourist generating markets, the size of the sources of demand, the situation of resources in relation to the main tourist flows, and competitive and complementary tourism facilities [12]. Product of cultural tourism is a combination of appeal of the main (cultural and historical monuments, events and services of the museum, memorials or guiding tours) and the supplementing product (location, accommodation, transportation, general tourism services, offers, tourist information centers, transport

8 Results of the project Support to the Implementation of the National Strategy of tourism development in Serbia 2010-2012 indicate the need to place the emphasize on the historical round tours, stories, legends, myths and their interpretation in an innovative way in the tourist offer of Serbia, based on experience and the new experience, which represents a guideline for the development of cultural tourism, as well as the opportunity which the sector of protection of intangible cultural heritage cannot miss (European Commission 2010-2012).http://www.humandynamics.org/refere nce/support-implementation-national-strategy-tourism (12. 21. 2014). 
infrastructure) as well as elements of the general tourism product [13].

These elements of cultural tourism product in Serbia are often not well connected and therefore it is often difficult to reach some of the most attractive destinations, and the local government expects only to gain, without any prior investment. Hence cultural heritage is not used enough as a tourist potential so far. Such is the case with some tourist routes such as "The cultural route of the Roman emperors". This route, which refers to the 17 Roman emperors born on the territory of Serbia, has a well determined tourism itinerary. However, there is insufficient cooperation between archaeological sites and ancient tourist attractions in terms of the harmonized working hours, accessible approach, and the overall level of equipment for visits, as well as the lack of professional staff at the sites (curators, local guides, animators) that are in charge of making visits more meaningful and attractive. ${ }^{9}$ There have also been cases that some cultural sites on this route were closed for various reasons (e.g. Mediana ${ }^{10}$ archaeological site near the town of Niš, was closed during the 1700th anniversary celebration of Edict of Milan 313-2013) in high season.

In recent years, the focus of interest in cultural tourism has shifted from the dominant tangible heritage (buildings, monuments, archaeological sites; works of art and artifacts in the museums) to the intangible heritage and products of cultural industries. Such an advance, despite all the positive aspects, hides certain dangers, primarily related to uncontrolled exploitation of these resources. For this reason, the management of cultural heritage as a whole requires a systematic effort, so that it remains accessible, not only to the current, but also to the future generations $[14,15]$.

The tourist offer based on cultural resources reaffirms mutual interplay between culture and tourism, and minimizes negative effects on local communities. While the promotion of tangible cultural heritage has a long tradition, intangible heritage is just beginning to take its place in the tourist offer $[16,17]$, particularly through the already-mentioned concept of creative tourism [18].

\section{Intangible Cultural Heritage as a Resource for Tourism Development in Serbia}

Serbia ratified the UNESCO Convention on the safeguarding of the intangible cultural heritage in 2010 . However, intangible cultural heritage did not get its place in the positive legislation of the Republic of Serbia until December 2016 [19]. In such a situation, the provisions of the Convention apply, as it is a legal act which takes

9

http://www.serbia.travel/culture/the-cultural-route/Put-kultur-rimskih-impr atora.a-131.640.html

$10 \mathrm{http}: / /$ www.visitnis.com/mediana.html precedence over the one currently in force, i.e. the incomplete Law on Cultural Property from $1994 .{ }^{11}$ By the ratification of this Convention, Serbia has pledged to undertake measures to ensure the conservation of intangible cultural heritage within its territory and to adopt appropriate legal, technical, administrative and financial measures in order to strengthen institutions for education in the area of managing intangible cultural heritage, while guaranteeing access to the intangible cultural heritage. ${ }^{12}$ Guarantor for the fulfillment of those obligations is precisely the adoption of appropriate laws which would provide legal frameworks for the preservation of intangible cultural heritage in Serbia. Thus, the work of the professional bodies and institutions that oversee the implementation of the Convention would gain importance, and bearers of elements of the intangible cultural heritage recorded and submitted to the National Register would be reassured that their rights and obligations, which they have gained by the nomination, will be implemented in practice.

In order for the system of protection of intangible heritage in Serbia to be adequately implemented, network of protection was established, which changed over time. The network consists of National Committee for the Intangible Cultural Heritage (ICH), Centre for the Intangible Cultural Heritage in the Ethnographic Museum in Belgrade, the Network of regional coordinators and the Commission for Inscription of the Intangible Cultural Heritage Registry also located in the Ethnographic Museum.

The first entries in the National Registry were conducted in 2012, when 27 elements were proposed and accepted from the entire territory of Serbia: The Slava, Serbian family Saint Patron's Day, (celebration of a particular Saint), Prayer (St. George's Day Ritual); Belmuž (traditional shepherds' dish from Eastern Serbia made of young sheep's cheese and corn flour); Ritual of making and lighting farmer candles; Makin of Pirot hard cheese; Rug-making in Pirot; Filigree craft (Krist Berisha, a silversmith from Kraljevo); Stonemasonry (the village of Bela Voda near Kruševac); Mantije - meat pie from Novi Pazar prepared in traditional way; Zlakusa pottery (traditional hand-wheel pottery-making in Western Serbia); Kosovo-style embroidery; Singing accompanied by gusle (a single-stringed bowed musical instrument); Groktalica singing - lyrical-epic decasyllabic folk songs that were sung by taking a deep voice from the throat, unaccompanied with any instruments; Singing izvika (Clamor singing); Era-style humor from Western Serbia; Kolo dance (three steps kolo, six steps kolo) - Serbian folklore dancing; Rumenka kolo national Serbian dance; Bagpipes playing; Kaval playing; Pipe-playing practice; Slovak naive art painting in Kovačica;

11 Službeni glasnik RS 71/94. (Public Enterprise Official Gazette is the official newsletter).

12 Convention for the Safeguarding of the Intangible Cultural heritage, article 11-13

(http://www.kultura.gov.rs/docs/stranice/82128418889499865927/11.\%20

Konvencija\%20o\%20ocuvanju\%20

nematerijalnog\%20kulturnog\%20nasledja\%20\%28Pariz\%202003\%29.pdf) (12.21.2014). 
Lazarice, traditional procession during the Orthodox feast of St. Lazarus Saturday in Sirinićka parish; Wooden flask-making in the village of Pilica; Vuk's Convocation (Vuk Stefanović Karadžić was a philologist, a reformer of Serbian language, collector of folk literature and the author of the first dictionary of Serbian language); Ojkača singing, original songs from the Krajina-Dinara region; City song from Vranje and the so-called Guarding Jesus Christ's Tomb, one of the most unusual and interesting customs related to Easter. Until December 2016, seven more elements are inscribed in the National Registry of ICH: St. Georg Patrons's Day; Plum brandy making; Craft of coppersmith; Rug-making in Stapari; Kajmak making (special kind of cream) and Cipovka making (special kind of bread from Vojvodina province).

Since November of 2014, Serbia has one element inscribed on the Representative List of the Intangible Cultural Heritage of Humanity, the Slava - family Saint Patron Day. ${ }^{13}$ Its listing was greatly acclaimed by the local public, and by this act, the whole area of intangible cultural heritage gained in visibility. ${ }^{14}$

In parallel with the preparation of some of the elements from the National Registry for the inscription on the UNESCO list, the work on the collection and recording of elements of intangible cultural heritage is intensified in Serbia, so that it is preserved, developed and adequately evaluated. Cultural institutions and local communities are working on recognizing the value of cultural heritage, preservation, maintenance and development of a living human heritage and improving the social and legal status of the holders of intangible cultural heritage and heritage in general. However, it still lacks specific promotional campaigns and the systematic approach of these resources for the purpose of tourism. Analysis of the current situation shows that the Serbian tourist offer of intangible heritage is represented in a very limited extent. The role of local tourism organizations is essential for their promotion and increased visibility since they know best the values "on their territory" for the purposes of tourism. The experience of countries where cultural tourism is established with well-designed programs shows that tourist offer cannot be separated from the needs and sensibilities of the local communities. Programs made for the needs of the local community will attract tourists, while those made for tourists will only attract tourists, which puts in question their validity and sustainability [20].

\section{Participation of Intangible Cultural Heritage in the Tourist Offer of Serbia}

13

http://nkns.rs/2014/11/slava-na-uneskovoj-reprezentativnoj-listi-nematerija lnog-kulturnog-nasledja-covecanstva/ (12.21. 2014).

14 By entering key words "family saint patron day on the UNESCO list" on Google search on $4^{\text {th }}$ of January 2017. 998,000 results were obtained.
By the analysis of the first 27 elements of intangible cultural heritage from the National Registry, a group of authors tried to make their tourism valorization using the Hilary du Cros method [21]. The factors evaluated were related to the market attractiveness of the elements of intangible heritage (the value of the environment, whether it is known outside the local community, as well as the value of national symbols, revival of cultural sites, its specificity compared to surrounding attractions, attraction for specific needs, complementarity with other resources in the area, association with other cultural amenities, attractiveness, accessibility, transport possibilities, proximity to other attractions and service facilities at the destination), as well as elements of cultural significance and sensitivity of cultural property (aesthetic, historical, educational, social and scientific research value, representativeness, sensitivity, state of preservation, management, monitoring, investment potential and the possibility of negative impacts of modifications and a large number of visitors) [22]. ${ }^{15}$

The analysis showed that not all of the 27 elements of ICH have the same potential to be a part of cultural tourism offer of Serbia. Top rated in both categories were Kolo (102 points), Prayer under Midžor (102), Vuk's Convocation (101), St Patron's day (96), Slovak naive art painting (95) and Zlakusa pottery (95) [23].

The most points in this valorization were awarded to Kolo, a traditional folk dance in Serbia, nominated for the inscription on the UNESCO Representative List of the Intangible Cultural Heritage of Humanity in 2017. Kolo is still practiced in rural and urban areas, during the celebration, but also in a very informal occasion, whenever the appropriate music is played. This dance is a great possibility of presentation of $\mathrm{ICH}$, with which all the inhabitants of Serbia identify with, regardless of gender, age and religion. That provides a wide range of possibilities for utilization within the cultural tourism, whether it is organized visits to festivals, feasts and celebrations at which the Kolo is performed or creative workshops that enable tourists to learn the traditional dance.

Rated second was Prayer under Midžor as a commercial event, which fallows the traditional St. George's ceremony at the foot of Stara Planina, near Knjaževac town, for twenty years. In 2014 this event has won the award for the best tourist destination in the competition EDEN Tourist Organization of Serbia on the theme "Tourism and local intangible cultural heritage". ${ }^{16}$

Vuk's Convocation, on the third place, organized by the

15 Besides undeniably important results of this analysis, its disadvantage is that only tourism experts participated in the evaluation of elements of intangible cultural heritage. Valorization of some of the factors represented here can only be done by the specialists dedicated to the protection of cultural heritage, which in this case were not present (author's note).

16 Knjževac, the winner of the competition for the selection of "Outstanding destination in Europe" in Serbia:

http://www.srbija.travel/knjazevac-pobednik-konkursa-za-izbor-izuzetne-d estinacije-evrope-u-srbiji/. This manifestation also includes the preparation of belmuž which is also in the national registry Intangible Cultural Heritage of Serbia. 
Cultural Centre "Vuk Karadžic" from Loznica town, is the oldest cultural event in Serbia. ${ }^{17}$ Its objective - cherishing of Serbian language and literature, has become topical, and therefore the Museum of Language was formed where toponyms and points are collected out the importance of stories and narratives, with the idea that the object supports the story and not the other way around. The manifestation itself, with its long duration and institutional organization, ensures sustainability and thus stands out as an example of good practice. Vuk's Convocation represents an example of good practice in the course of several decades working on preservation, language, writing, oral literature, folklore, translation and other activities related to the Serbian language, literature and tradition. Workshops during Vuk's Convocation held in Tršić village, which are upgraded over time, may represent an attractive destination for domestic tourists, school field trips and certain categories of foreign tourists.

The following is Slava - Saint Patron's Day. According to the official description of Slava, the first and only Serbian element of ICH inscribed in the UNESCO Representative List of the Intangible Cultural Heritage of Humanity, it is "a complex of ritual and social practices celebrating a saint that is believed to be a family's patron and a giver of prosperity. The celebration of the family patron saint is practiced by most Orthodox Christian families throughout the Republic of Serbia as an important family holiday involving individual families and their guests - members of the extended family, neighbors, friends, and local community members." 18 Although it is a family and not a public act, celebration of Slava could be converted into an exclusive tourist attraction by well-designed programs of travel agencies which could connect tourists with families willing to share their family traditions with them.

The customs and traditions of ethnic minorities (Romani, Slovaks, Vlachs - an ethnic minority in eastern Serbia, culturally and linguistically related to Romanians, Hungarians, Ruthenians, Šokci, an ethnographic group of South Slavs mainly identified as Croats, Bunjevci, ethnic group living mostly in the Bačka region of Serbia in the Autonomous Province of Vojvodina, Albanians, Bosnians and others) add to the value of the tourist offer of Serbia because "intangible cultural heritage legacy of the modern and dynamic process as it is, is protected and valued, becoming the exclusive good of different cultures" [24].

Next, Slovak naive art painting [25] in the Register of intangible cultural heritage of Serbia is an important component of the tourist offer of the municipality Kovačica. ${ }^{19}$ Through the motto "The Whole Settlement - an Art Atelier" the local community, led by Pavel Babka, the owner of Babka Gallery, systematically and continuously promotes the naive art of Slovaks and maintains the interest

17 http://www.ckvkaradzic.org.rs/sabori.html (12.23.2014)

$18 \mathrm{http}: / / w w w . n k n s . r s / e n / p o p i s-n k n s /$ saint-patrons-day (01.05.2017)

$19 \mathrm{http}: / /$ www.paunpress.com/user/tur.php?id=979 (12.23.2014). of domestic and international public. ${ }^{20}$ This element is highly valorized as a tourist potential of Serbia due to its visual attractiveness.

Finally, Zlakusa pottery-making, which is among the most famous from the List of Intangible Cultural Heritage of Serbia, in the recent decades recorded a constant increase in the public interest, but also showed that the mere awareness of local communities about the importance of heritage is not enough. Since the nineties, when this particular way of making pots on the hand wheel was disappearing, to date, the number of potters had multiplied [26]. Increased demand for their products and noticeably greater interest in the village itself encouraged the entire community to make their potential more sustainable. Thus were created: Ethno park "Terzića avlija" which aims to deal with the exhibition and tourism activity, and also organizes environmental programs; ${ }^{21}$ Ethno association "Zavičaj" which brings together folk performing groups of different ages and organizes events such as the "Zlakusa in song and dance" and "Singing Yard"; ${ }^{22}$ Association of potters "Zlakusa" whose main purpose is to preserve authentic technological process, improve quality and fight against counterfeiting of Zlakuska products [27]; ${ }^{23}$ Women's Association "Zlakušanke" which brings together local women skilled in preparing traditional meals etc. ${ }^{24}$ The event which should promote Zlakusa pottery - "Pottery fest", within a broader manifestation "Autumn in Zlakusa" involving all the mentioned associations, although initially well-conceived it failed to cope with the demands of the wider community leading to the replacement of the hand-wheel and the bonfire -žižanica $[28,29]$ with loud music in the tents. Zlakusa pots at the recent event entitled "Demonstration of building pots and roasting on an open fire", were underrepresented, while during the first years they were the most important part of the program. ${ }^{25}$ This example shows how uncontrolled exploitation of cultural resources can lead to a phenomenon that can endanger the cultural good itself. The risks and damage can be avoided if the local community cooperates with the institutions for the protection of cultural heritage and with the local tourism organizations. The synergy of these three entities ensures the sustainability of the elements. This is the key strategy for the development and the protection of intangible cultural heritage and cultural tourism as well [30].

These elements of intangible cultural heritage, and those

20 Naive painting of Slovaks were a part of the presentation of cultural values of Serbia at EXPO 2010 in Shanghai

(http://www.fareastsociety.org.rs/Dodjite $\% 20 \mathrm{u} \% 20$ sangaj\%20zagrlite $\% 20 \mathrm{~s}$ vet $\% 20-\% 20$ Kovacica.pdf; 23.12.2014), and in 2012 an exhibition of paintings from Kovačica was hosted in Brussels.

$21 \mathrm{http} / /$ www.zavicaj.info/etno-park-terzica-avlija/ (12.21.2014).

22 http://www.zavicaj.info/folklor/ (12.21.2014).

23 The Association has registered the trademark, and began the process for obtaining the designation of origin issued by the Intellectual Property Office.

24 http://www.zlakusa.com/stanovnistvo/aktivnosti-zena-iz-sela-zlakusa/ (12.23.2014)

25 These observations were made during the Pottery fest held on the 7 th of September 2014. (prim. B. Djordjević). 
have a lower ranking in the aforementioned analysis, often do not represent independent tourist attraction, but more often represent complementary values [31]. Even when they can be regarded as autonomous tourist attractions, such as the Zlakusa pottery, the association with other elements of intangible and tangible cultural heritage contributes to their attractiveness through presentation in the context.

The results of this analysis, with results of the project "Support to the implementation of the National Strategy for Tourism Development in Serbia" which are shown in the next chapter, can significantly contribute to improving the utilization of elements of intangible cultural heritage in the tourist offer of Serbia.

\section{Cultural Factors in the Revision of the Strategy for the Development of Tourism in Serbia}

The project "Support to the implementation of the National Strategy for Tourism Development in Serbia" ${ }^{26}$ (2010-2012) funded by the European Union aimed to encourage greater contributions to tourism in the Serbian economy in line with the best practice in the EU [32]. In this regard, the research needed for the purpose of the revision of Tourism Development Strategy, was conducted by the Agency dealing with market research and public opinion "MASMI" from Belgrade, which is a part of the research network "MASMI Research Group" based in London. The sample included 1,500 tourists. ${ }^{27}$ Research findings have pointed out possible directions of development of tourism in Serbia. Thus, one third of tourists visit Serbia several times a year (31.8\%), 35.3\% visit every year, and $15 \%$ do so every two years. Annually, Serbia attracts $7.5 \%$ of the "newcomers". The main motive for the arrival of tourists is their satisfaction (37.1\%) and entertainment (20.7\%). Research results confirm that the travelers decision for picking Serbia as a destination is led by the diversity and quality of supply (27.8\%), the selection of local food and beverages $(21.1 \%)$ and the prices $(18.7 \%)$. Over $32 \%$ of travelers are motivated by good previous experiences while every fourth tourist is drawn by the good atmosphere and the overall look.

In the cultural offer, events and entertainment influence the commitment to visit Serbia (42.4\%) the most, while the cultural and artistic programs account for $15.9 \%$; and urban landscapes, layout and architecture $13.4 \%$ of the visits.

The data indicates that the intangible culture remains unrecognized and insufficiently presented to tourists, although it is undoubtedly incorporated into the above-mentioned elements. There is an impression that

26 http://mapa.euinfo.rs/home/details/239 author B. Krasojević participated in its creation

27 In Belgrade 20\%, Western Serbia (Zlatibor) 13\%, Kopaonik 12\%, Lower Podunavlje (2\%), Novi Pazar (1\%). constant analysis and market research in culture and tourism are necessary, particularly at the local level. Projects within the cultural tourism require the selection of cultural resources, ideological concept with an accompanying interpretation, development and financial structure, implementation, promotion, monitoring and evaluation of the cultural attractions [33].

The revision of Serbia Tourism Development Strategy has identified possible strategic directions for further development of tourism at the national level. According to the results of this project [34], the chances of Serbia utilizing its cultural potential are growing, especially in regards of the new tourism markets and attracting tourists in their "mature years". It has been confirmed that the culture is a powerful motive for the arrival of tourists in Serbia, especially those who do so for the first time. It is suggested that the cultural tourist offer should focus on the historical round tours, myths and interpretations of interesting phenomena and events in an innovative way, focusing on the experience. Local culture, the way of life and traditions, especially in Europe, are important factors of attraction, especially for tourists with lower incomes and those interested in new tourist markets with moderate prices, such as Serbian is. This suggests that the expansion of the markets, in which the tourist offer is based on cultural resources, could be successfully marketed. In conclusion, planning the development of cultural tourism product must include all stakeholders - government institutions, local authorities, representatives of the tourism industry and cultural institutions, regional and local tourism organizations, Serbian Orthodox Church, regional development agencies, tourist guides and others who benefit from the development of cultural products, and whose attitudes and opinions are relevant in the planning and decision-making process.

\section{Conclusions}

Intangible cultural heritage is the very essence of cultural heritage in general since all the tangible elements of cultural heritage became cultural goods thanks to their intangible characteristics (way of production, artistic achievements, functions, etc.). It is therefore surprising that, globally, ICH is recognized as an important segment of the cultural heritage only in the Convention of 2003. Connecting the tangible and intangible cultural heritage is the essence of the modern tourist offer, which gains in its quality and attractiveness through such an approach. Since Serbia deals with the protection of ICH for 16 years, it is surprising that a stronger cross-sector connection has not occurred between culture and tourism. Intangible cultural heritage is insufficiently represented and valued in the tourist offer of Serbia. Mostly, it makes up only a fraction of the content of the tourist manifestations, it lacks an adequate distribution and often it is misrepresented by unsuitable presentation and selling. However, intangible culture could become maxime armata if 
it became more involved in tourism programs of tour operators and tourist organizations. The integral approach, which resembles a mosaic of tangible and intangible cultural resources that are connected in order to make a unique tourism product, is the most recommended.

The essence of intangible cultural product in tourism is its interpretation which is supposed to enable tourists to experience the culture in the past and the present. In that sense, it is crucial to build partnerships and start joint projects with all interested parties while simultaneously preserving intangible cultural heritage. It is necessary to make an overview and coordinate the laws, rules and regulations which have to deal with intangible cultural heritage that is of importance for tourism of Serbia in order to provide quality presentation and interpretation by the tourist guides, prevent illegal selling and protect the intellectual property rights regarding the craftsmanship of the souvenirs and other elements based on intangible cultural heritage (traditional music, culinary recipes, cosmetics, medical supplements). The local government in cooperation with tourist organizations should recognize, protect and adequately present their cultural-historical identity through intangible elements of the cultural heritage as well. A good example would be numerous manifestations, celebrations, fairs, old arts and crafts, customs, feasts, traditional beliefs, specialized small museums (such as the Museum of bread in Pećinci or Museum of honey and wine in Sremski Karlovci), traditional music, folklore, preparation and degustation of local gastronomic specialties etc.

In order to increase the competitiveness of the cultural-tourism products of Serbia, it is necessary to discover and understand the motives of tourist demand and also needs and abilities of tourist destination, apropos the local community. Tourist offer must activate the process of creation of the cultural knowledge through revived and not "dormant" cultural heritage. The strategy of tourism development of Serbia (2006-2015) offered a matrix of attractions and competitiveness of tourism products, and its revision (2010-2012) confirmed through the project "Support to the implementation of the National strategy for tourism development in Serbia", that the big cultural potential of the country could enhance socio-economic development, livelihood and straighten foreign exchange as well as create new work places. Despite of this verification, Serbia did not develop a competitive cultural-tourism offer that is based on the tangible, but especially intangible cultural heritage. The offer should also include an organized sale of the products based on the intangible heritage through the media and licensed salesmen (souvenir shop, museum, airport, hotel, tourism agencies and tourist organizations). The possibilities are numerous, but only systematic cross-sectoral approach will enable controlled exploitation of these resources to contribute to their sustainability and development of culture, tourism and society in general.

\section{REFERENCES}

[1] B. Djordjević. Intangible Cultural Heritage - An Analysis of the Traditional Pottery Production Related Legislation (Original: Nematerijalno kulturno nasledje - analiza pravnog okvira na primeru tradicionalne keramičke proizvodnje), National Museum, Belgrade, Museological Vol. 15, pp. 15-60, 2012.

[2] M. Popović-Živančević. Integrative protection of heritage with the methodology of preventive conservation (Original: Integrativna zaštita baštine sa metodologijom preventivne konzervacije), Central Institute for Conservation, Belgrade, 2012 .

[3] E. Delgado. "L'art del turisme”. In: Belda, E., Garcia, S. (eds.). Tourism and culture (Original: Turisme i cultura). Fundacio Interarts, Barcelona, p. 101-108, 2001

[4] G. Richards. Cultural Tourism: Global and local perspectives. Haworth Press, New York, p. 329-339, 2007.

[5] G. Richards. Cultural tourism trends in Europe: a context for the development of Cultural Routes. In: Khovanova -Rubicondo, K. (ed.) Impact of European Cultural Routes on SMEs' innovation and competitiveness, Council of Europe Publishing, Strasbourg, p. 21, 2011.

[6] UNWTO. Global forecast and Profiles of Market Segments, Tourism 2020 Vision, Madrid, Vol. 7, p. 71, 2011.

[7] R. Conrady, M. Buck. Trends and Issues in Global Tourism 2010, Springer, ITB, Berlin, p. 185, 2010.

[8] G. Richards, C. Raymond. Creative Tourism. ATLAS News No. 23, p. 16-20, 2000.

[9] W. Nuryanti. Heritage and Postmodern Tourism. Annals of Tourism Research, Vol. 23, p. 250, 1996.

[10] B. Djordjević. "Ecomuseums and creative Tourism - The Untapped Potential of Serbia”. In: B. Djordjević (ed.), Museums and Cultural Tourism. Connecting differences, p. 114-125, 2015.

[11] B. Krasojević. Strategic management of cultural resources in tourism of Serbia (Original: Strateško upravljanje kulturnim resursima u turizmu Srbije), [unpublished dissertation], Singidunum University, Belgrade, p. 349, 2013.

[12] B. Mc Kercher, H. du Cros. Cultural tourism - The Partnership Between Tourism and Cultural Heritage Management, The Haworth Hospitality Press, New York, p. 47, 2002.

[13] M. Sigala, D. Leslie. International Cultural Tourism: Management, implications and cases, Oxford, pp. 28-29, 2005 .

[14] A.D. Jelinčić. Culture in a shop window (Original: Kultura u izlogu), Intermedia, Zagreb, p. 26, 2010.

[15] B. Mc Kercher, H. du Cros. Cultural tourism - The Partnership Between Tourism and Cultural Heritage Management, The Haworth Hospitality Press, New York, p. 43, 2002.

[16] Dž. Stjuard. Theory of cultural change (Original: Teorija kulturne promene), BIGZ, Belgrade, p. 9, 1981. 
[17] Bandić, Dušan. "Kingdom of earth, kingdom of heaven" (Original: "Carstvo zemaljsko, carstvo nebesko"), BIGZ , Belgrade, p. 240, 1997.

[18] G. Richards, C. Raymond. Creative Tourism. ATLAS News No. 23, p. 16-20, 2000.

[19] B. Djordjević. Intangible Cultural Heritage - An Analysis of the Traditional Pottery Production Related Legislation (Original: Nematerijalno kulturno nasledje - analiza pravnog okvira na primeru tradicionalne keramičke proizvodnje), National Museum, Belgrade, Museological Vol. 15, p. 55-58, 2012.

[20] D. Ripkema. Heritage and the creative economy (Original: Nasledje i kreativna ekonomija), lecture on the Second Forum of Creative Economy, in the organization of the Group for Creative Economy, Palace of Serbia, November 7th 2014.

[21] Ž. Bjeljac, A. Terzić, N. Ćurčić. Tourismological valorization of intangible cultural heritage of Serbia. According to the Hilary du Cros method. Issues in Ethnology and Anthropology, n.s. Vol. 9, Is. 1 (2014), p. 195-217.

[22] Ž. Bjeljac, A. Terzić, N. Ćurčić. Tourismological valorization of intangible cultural heritage of Serbia. According to the Hilary du Cros method. Issues in Ethnology and Anthropology, n.s. Vol. 9, Is. 1 (2014), p. 198.

[23] Ž. Bjeljac, A. Terzić, N. Ćurčić. Tourismological valorization of intangible cultural heritage of Serbia. According to the Hilary du Cros method. Issues in Ethnology and Anthropology, n.s. Vol. 9, Is. 1 (2014), p. 199 - Tab. 1, p. 208 - Tab. 2.

[24] M. Lukić Krstanović, Z. Divac. Programming of intangible cultural heritage of the city (Original: Programiranje nematerijalnog kulturnog nasleđa grada), Glasnik etnografskog instituta SANU LX (2), Belgrade, p. 12, 2012.

[25] G. Blagojević. Naive painting as the story of ethno-cultural identity of the Slovaks in Serbia: the case of Kovačica (Original: Naivno slikarstvo kao priča o etnokulturnom identitetu Slovaka u Srbiji: primer Kovačice), Zbornik Matice srpske za društvene nauke, 139(2), p. 185-195, 2012.
[26] B. Djordjević. "Ethnoarchaeological Research as a Method of Protection of Traditional Ceramics Technologies" in: M. Popovi-Živančević (ed.) Condition of the Cultural and Natural Heritage in the Balkan Region, Vol. 1, Proceedings of the Regional Conference held in Kladovo October 2006, Belgrade, p. 87-99, 2007.

[27] B. Djordjević. “Ethnoarchaeological Research as a Method of Protection of Traditional Ceramics Technologies" in: M. Popovi-Živančević (ed.) Condition of the Cultural and Natural Heritage in the Balkan Region, Vol. 1, Proceedings of the Regional Conference held in Kladovo October 2006, Belgrade, p. 87-99, 2007.

[28] B. Djordjević. Three facets of traditional pottery making in Serbia, National Museum, Belgrade, p. 35-55, 2011.

[29] P. Tomić. 1983. Pottery-making in Serbia (Original: Grnčarstvo u Srbiji), Ethnographic Museum, Belgrade, 1983.

[30] B. Djordjević. "Ecomuseums and creative Tourism - The Untapped Potential of Serbia". In: B. Djordjević (ed.), Museums and Cultural Tourism. Connecting differences, $\mathrm{p}$. $114-125,2015$

[31] Ž. Bjeljac, A. Terzić, N. Ćurčić. Tourismological valorization of intangible cultural heritage of Serbia. According to the Hilary du Cros method. Issues in Ethnology and Anthropology, n.s. Vol. 9, Is. 1 (2014), p. 195-217.

[32] B. Krasojević. Strategic management of cultural resources in tourism of Serbia (Original: Strateško upravljanje kulturnim resursima u turizmu Srbije), [unpublished dissertation], Singidunum University, Belgrade, p. 218-222, 2013.

[33] D.A. Jelinčić. Tourism vs Identity Globalization and Tradition (Original: Turizam vs Identitet Globalizacija i tradicija), Etnološka istraživanja, Institut za međunarodne odnose Zagreb: p. 161-183, 2006.

[34] B. Krasojević. Strategic management of cultural resources in tourism of Serbia (Original: Strateško upravljanje kulturnim resursima u turizmu Srbije), [unpublished dissertation], Singidunum University, Belgrade, p. 330, 2013. 